\title{
Study Inhibitory Effect of Alhagi Extract on Oral Microorganisms
}

\author{
Wasan Mohammed Alsewidi \\ BSc, MSc, Al-Maaref University College, Department of Dentistry, Iraq.
}

Corresponding Author: Wasan Mohammed Alsewidi, BSc, MSc, Al-Maaref University College, Department of Dentistry, Iraq.

Received date: November 11, 2021; Accepted date: December 17, 2021; Published date: January 06, 2021

Citation: Wasan M. Alsewidi (2022) Study Inhibitory Effect of Alhagi Extract on Oral Microorganisms. J. Obstetrics Gynecology and Reproductive Sciences; 6(2) DOI:10.31579/2578-8965/106

Copyright: () 2022, Wasan Mohammed Alsewidi, This is an open access article distributed under the Creative Commons Attribution License, which permits unrestricted use, distribution, and reproduction in any medium, provided the original work is properly cited.

\begin{abstract}
Many studies determined effect of plant extract on plant pathogens and human pathogens. Alhagi maurorum is considered as one of the important medicinal plants in Iraq. It is used for urinary tract infection, rheumatic pains and liver disorders. Study the Inhibition Effect of Alhagi extract on oral microorganisms as Streptococci, Actinobacillus and Staphylococci, with (0,10, 50 and 100 percentages). The concentrations of $0 \%$ has not any inhibition effect, $10 \%$, has a slight inhibition effect against oral Streptococci and Actinobacillus, but has not effect on Staphylococci. 50\%, has an inhibition effect against oral Streptococci more than E-coli, but has not effect on Staphylococci, but 100\%, has a wide inhibition effect a against oral Streptococci more than Actinobacillus except Staphylococci has not effect. The lack of inhibition effect at the concentration of $0 \%$ and $10 \%$ of Alhagi maurorum aqueous extract may be returned to the limits or decline of active components in these low concentrations of aqueous extract. In addition, studies indicate that there are many factors have an effect in the minimizing the impact of plant extracts.
\end{abstract}

Key words: alhagi extraction; antioxidant; antimicrobial; bioactive compound; pathogenic bacteria

\section{Introduction:}

Alhagi maurorum is considered as one of the important medicinal plants in Iraq. It is used for urinary tract infection, rheumatic pains and liver disorders [1]. In addition, this plant may be used as an alternative solvent to the use of drugs. Alhagi maurorum belongs to the family of fabaceae, and it produces numbers of biologically important second metabolites. The species of A. maurorum is legumes [2]. Since ancient times, herbs have been used to protect human and treat chronic health maladies in addition to flavor food improvement [3]. Herbal drugs are playing an important role in the health care programs in world [4]. Herbs always have been using for flavor or fragrances in food industries but little of them had exhibiting properties of antimicrobial $[5,6]$.

The last researches observed that Alhagi maurorum contain wide secondary metabolite like flavonoid, coumarin, fatty acid, unsaturated sterol, glycoside, sterol, resin, steroid, carbohydrate, vitamin, alkaloid, tannin and triterpene. It exerted anti-inflammatory, antibacterial, analgesics, antipyretic, antioxidants, gastrointestinal, diuretic, cardiovascular, and dermatologically as well as wide other effects [7]. Scientists had study as well as analyze impact of various solvent types like methanol, ethyl alcohol, hexane and water for the goal of antioxidant extractions from different plant parts like seeds and leaves. Therefore, extracted various [phenolic compounds] from plant with high degrees of accuracy, different solvents of varying polarity must have been used [8, 9].

\section{Methods}

Sixty samples divided into 20 samples for each oral microorganisms, 5 samples for each concentration, were taken from patients in private dental clinic. Sterile cotton swaps were used for this research, these samples were taken from patients who have sever gingivitis as well as gum bleeding. Sterile cotton swaps are flooding in stuart transport medium and laboratory cultured, using blood agar medium to make a checks specialized to oral Streptococci, Actinobacillus and Staphylococci, finding the producers of dextran, anaerobic growth and mannitol fermentation using (Brain heart infusion broth). Doses of the isolated bacteria are injecting in tubes contain this medium as well as sucrose. Putting glass bars in these tubes and inculcated at $\left(37^{\circ} \mathrm{C}\right.$ for 24 hours) [10].

\section{Collection of Alhagi Maurorum}

In this study, we use the leaves, steam and roots of a plant and classified in the laboratories of Basic - Education College - department of science at Baghdad University. Plant was dried in shade and then grinded to get a homogeneous powder then saved until utilized [1].

\section{Preparation of Aqueous Extract of Alhagi Maurorum}

$10 \mathrm{gm}$ of prepared powder were taken and put in flask $100 \mathrm{ml}$ of distil water were added, and let the infusion for 48 hours. Centrifuge was used to starts the precipitation at 2000 cycle/minute for 10 minutes. Fluid were used after pass through filter papers. Extract prepared at the 
concentrations of $0 \%$ (control), $10 \%, 50 \%$ and $100 \%$, using sterilized distil water, saved at $4{ }^{\circ} \mathrm{C}$ and used during 2 weeks only [11]. MullerHinton agar used to culture the oral Streptococci, E-coli and Staphylococcus isolate holes make at the medium at 5-millimeter diameter. 100 microliters of extract put at the holes to all the prepared concentrations in addition to the founded of controlled sample [12].

\section{Results and Discussion}

Table one showed that the use of different concentrations of Alhagi maurorum extract were used for three types of organisms. The concentrations of $0 \%$ has not any inhibition effect against oral microorganisms, when we used the concentration of $10 \%$, has an slight inhibition effect against oral Streptococci and Actinobacillus, but has not effect on Staphylococci. When using 50\%, has an inhibition effect against oral Streptococci more than Actinobacillus, but has not effect on Staphylococci. Using $100 \%$, has a wide inhibition effect against oral Streptococci more than Actinobacillus except Staphylococci has not effect.
Many studies showed that Alhagi maurorum contains many active components have an inhibition effect against oral microorganisms. Since the medicinal plants antibacterial effective of differ dramatically according to the phytochemical characteristic of plant family and subfamily. It was not surprise to note the various in this efficiency until when samples used which takes of the same plants but of two various regions. The inhibition effect of Alhagi maurorum aqueous extract against oral Streptococci and Actinobacillus in agreement with Al-Lafi \& Ababneh, 1995 and Shan et al., 2007 that found this effect return to the founded of these active components by suspend the activity of oral bacteria in gingivitis case. The lack of inhibition effect at the concentration of $0 \%$ and $10 \%$ of Alhagi maurorum aqueous extract may be returned to the limits or decline of active components in these low concentrations of aqueous extract. In addition, studies indicate that there are many factors have an effect in the minimizing the impact of plant extracts against bacterial isolates such as Age, smoking or chronic diseases (as diabetes) in agreement with Lewis, 2003, and Sulaiman, 2013.

\section{Table 1: The effect of Alhagi extract concentration on inhibition of oral microorganisms}

\begin{tabular}{|c|c|c|c|}
\hline Name of bacteria & $\begin{array}{l}\text { Concentrations } \\
(\%)\end{array}$ & \begin{tabular}{|l} 
Result (zone of \\
inhibition)
\end{tabular} & \\
\hline Streptocpcci & $\begin{array}{l}0 \text { (control) } \\
10 \\
50 \\
100\end{array}$ & \begin{tabular}{|l} 
zero \\
$10 \mathrm{~mm}$ \\
$12 \mathrm{~mm}$ \\
$16 \mathrm{~mm}$
\end{tabular} & NNCL \\
\hline Actinobacillus & $\begin{array}{l}0 \text { (control) } \\
10 \\
50 \\
100\end{array}$ & \begin{tabular}{|l} 
zero \\
$10 \mathrm{~mm}$ \\
$11 \mathrm{~mm}$ \\
$14 \mathrm{~mm}$
\end{tabular} & NNCL \\
\hline Staphylococci & \begin{tabular}{|l} 
(control) \\
10 \\
50 \\
100
\end{tabular} & Resistance & \\
\hline
\end{tabular}

\section{References}

1. Nedhal, A., L. Al-Dour and Y. Al-Essa, (2010). Asurvay of plants used in lraq. Traditional medicine. Jordan Jourdnal of pharmaceutical sciences,; 3 (2): 100 - 108.

2. Duke, J.A .(2007). Duke's, handbook of medicinal plants of the Bible. usa. crc. press.

3. Panickar, K.S.(2013), Benefical effects of herbs, species and medicinal plants on the metabolic syndrome, brain and cognitive function. Cent. Nerv. syst. Agent Med. chem., 13(1): 13-29.

4. Raina, R.(1998), Side effects of some medicinal plants. Current science,; 75(9): 897-900.
5. Baharlouei A., Sharifi-Sirchi G.R., Bonjar G.H.S.(2010), (Identification of an antifungal chitinase from a potential biocontrol agent, streptomyces plicatus strain 101, and its new antagonistic spectrum of activity) Philipp. Agric. Sci.,; 93, P: 439-445.

6. Alaa Yaqoob Rahy, and Sabah Fadhil Al-Basrooqi, (2019). study the antibacterial activities of alhagi maurorum aqueous extract against oral streptococci isolated from gingivitis case, Plant Archives Vol. 19 No. 2,; pp. 4171-4174

7. Atta AH, Nasr SM, Mouneir SM, Alwabel NA and Essawy SS. (2012), (Evaluation of the diuretic effect of Conyza dioscorides and Alhagi maurorum) Int. J. Pharmcy and Pharm Sci.; 2 (3) P: 162-165 
8. Koffi E., Sea T., Dodehe Y., Soro S. (2010), (Effect of solvent type on extraction of polyphenols from twenty three ivorian plants) J. Anim. Plant Sci.,; 5, P: 550-558.

9. Salman, G.M. (2013). Antimicrobial and cytotoxic activities of methanol extract of Alhagi : maurorum. Afri. J. Microbial. Res.; 2 (4) P: 182-185

10. Remel Microbiology product, (1990) ; Technical Mannual. Techincal information. Lenexa. Kansas.

11. Harborae, J.B. (1984); Phyto chemical methods. Chapuan \& Hau. press. Newyork

12. Al-Bagieh, N.H. and K. Almas, Invitor antibacterial effects of aqueous and alcohol extract of miswak. Cairo Dent. J., (1997); 13: $211-240$.
13. Al-Lafi, T. and H. Ababneh, 1995; The effect of theextract of Miswak used in Jordan and Middle East on oral bacteria. lnt. Dent. J

14. Shan B, Cai YZ, Brooks JD, Corke H., (The in vitro antibacterial activity of dietary spice and medicinal herb extracts) Int J Food Microbiol, (2007);117, P: 112-9.

15. Lewis, J. (2003). Proteomices of oral pathogens : what we have learned. Philips institute pathogens and Granio facial Molecular Biology reports.

16. Sulaiman GM. (2013), (Antimicrobial and cytotoxic activities of methanol extract of Alhagi maurorum) Afr. J. Microbiol Res,; 7 (16) P: 1548-1557.

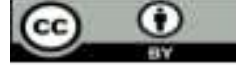

This work is licensed under Creative Commons Attribution 4.0 License

To Submit Your Article Click Here:

Submit Manuscript

DOI: $10.31579 / 2578-8965 / 106$
Ready to submit your research? Choose Auctores and benefit from:

$>$ fast, convenient online submission

$>$ rigorous peer review by experienced research in your field

$>$ rapid publication on acceptance

$>$ authors retain copyrights

$>$ unique DOI for all articles

$>\quad$ immediate, unrestricted online access

At Auctores, research is always in progress.

Learn more https://auctoresonline.org/journals/psychology-and-mental-healthcare 